\title{
THE OCCURRENCE OF JELLYFISH STINGS ON THE SANTA CATARINA COAST, SOUTHERN BRAZIL
}

\author{
Charrid Resgalla Jr.; Vitor CoutinhoGonçalves \& Antonio Henrique F. Klein
}

Centro de Ciências Tecnológicas da Terra e do Mar - CTTMar/UNIVALI

(Caixa Postal 360, Rua Uruguai, 458, 88302-202 Itajaí, SC, Brazil)

cresgalla@univali.br

The Santa Catarina coast is a major area tourism in Southern Brazil, and is visited by Brazilians from the southern and southeastern regions and neighboring countries (Hoefel \& Klein, 1998). During the summer season, bathers are frequently sting by jellyfish, i.e. by Cnidarians of the Hydrozoa, Scyphozoa and Cubozoa classes but these occurrences have only rarely been investigated.

However, incidents involving Cnidarians on the Brazilian coast have been the theme of studies carried out by Freitas et al. (1995) and Haddad Jr. et al. (2001 and 2002) on the southeastern coast and by Santos Lima et al. (1996) in the southern region of Brazil. The first aid care and treatment used have been described by the Fundação Nacional de Saúde (1999), Nonato (1992) and Haddad Jr. (2000).

This study presents an analysis of the conditions under which the incidents occur and the level of incidence on the Santa Catarina coast, as well as an assessment of the knowledge of the community regarding the first aid to be applied to victims.In accordance with an agreement between CTTMar/UNIVALI and the Corpo de Bombeiros do Estado de Santa Catarina (Santa Catarina Fire Service) entitled Projeto Segurança nas Praias (Beach Safety Project), incidents involving jellyfish and bathers on the Santa Catarina coast were recorded during three separate summer periods (1999/2000, 2000/2001 and 2001/2002). The project covered 16 counties and 28 beaches with lifeguard stations (Fig. 1A). At each station, the lifeguards were responsible for filling out forms about the occurrence of jellyfish stings. These forms included such victims' personal details as age; data about the beaches on which the incidents occurred; information on the type of incident (part of the body affected, type of reaction and medication used), and information as to the type of organism responsible for the incident (Fig. 1B). By means of jellyfish drawings, included on the form, the lifeguard and victim were able to provide an approximate identification of the class of organism that caused the incident.

The State of Santa Catarina was divided into three geographical areas (south, center and north) in order to map the occurrence of incidents and correlate these with the meteorological data available only for the north coast (Fig. 1A). The data on air temperature, rainfall, and wind direction and intensity were crossreferenced for the day of the incident. These data were obtained from the meteorological station of CTTMar/UNIVALI, in the town of Itajaí.

Of the total of 492 cases recorded during the three summer periods mentioned, over $75 \%$ of the occurrences involved children and adolescents between the ages of 5 and 15 years. These age groups are at greater risk due to the fact that the persons concerned spend more time in the water. However, it is also possible that these percentages have been overestimated, in view of the fact that adults do not normally seek the help of lifeguards when they suffer minor incidents. Legs and arms accounted for $60 \%$ of the body areas affected, given that these are the parts of the body primarily used for swimming and are below water level.

It must be emphasized that this is the first time this on-site methodology, which does not requir the victim to go to a hospital or a first-aid center for treatment has been used in Brazil,. Studies by Haddad Jr. (2001, 2002) in the southeastern region, and Santos Lima et al. (1996) in southern Brazil, are based on records of patients' entry into hospital and on reports received by the Centro de Informações Toxicológicas (Center for Toxicological Information) (CIT/SC). However, this kind of record gives scanty information and probably underestimates the importance of this type of incident, because many victims do not report to hospitals or first aid centers for treatment. Santos Lima et al. (1996) observed only 238 cases in 12 years, and emphasized that the year with the highest number of incidents coincided with the period in which the CIT/SC had held an advertising campaign.

In order to identify the organism or organisms responsible for the incidents, the information on the type of effect observed in the victims and the possibility of sighting the organism on the beach were analyzed. In $90.2 \%$ of the cases, the effects observed, such as erythemas and edemas, common reactions in the incidents involving cnidarians (Freitas et al., 1995), were local, producing systemic effects, such as vomiting and nausea, in only $9.8 \%$ of cases. 

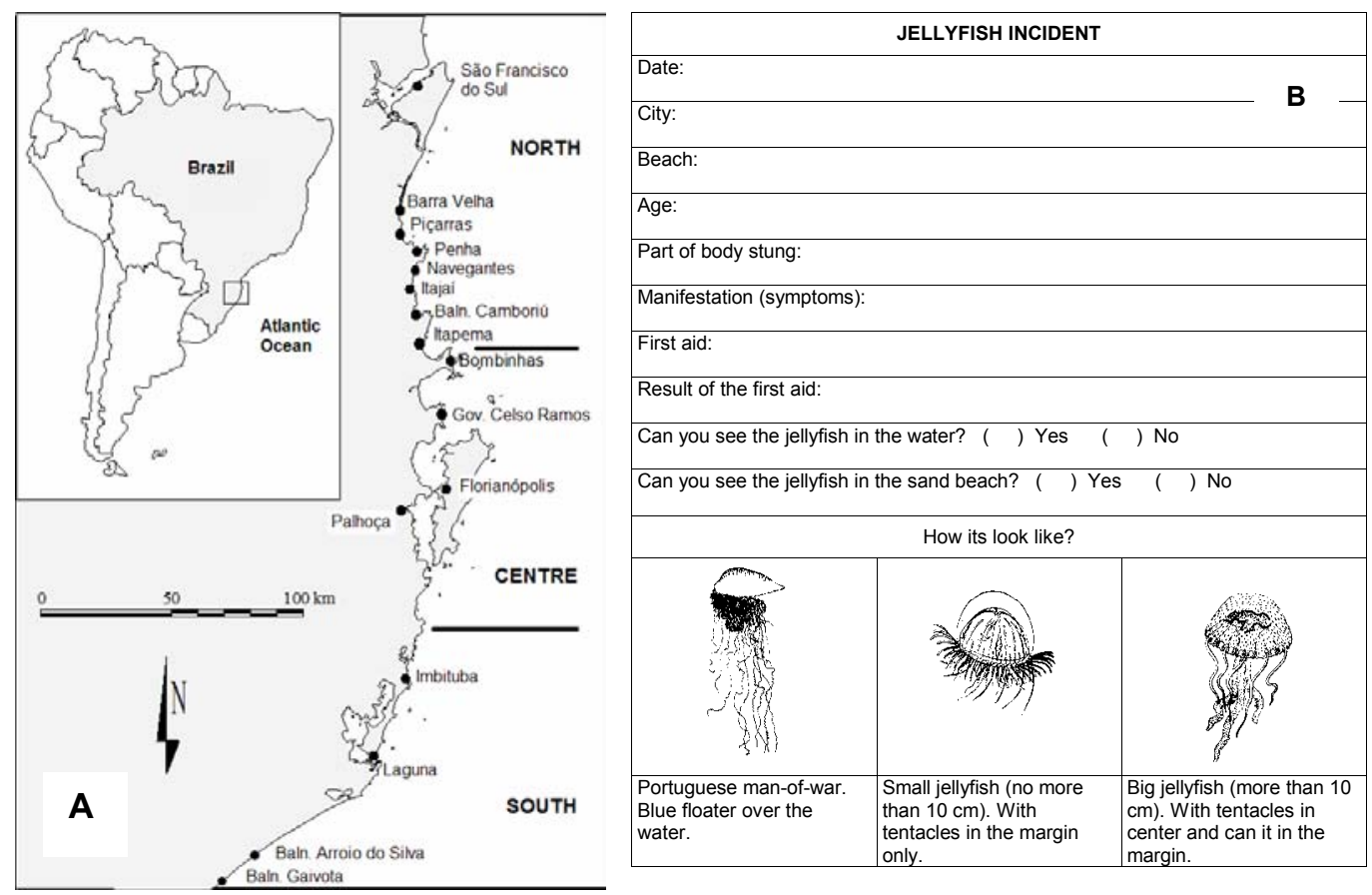

Fig. 1. A) Municipalities monitored for incidents involving jellyfish on the coast of Santa Catarina (Brazil) during three summers, from 1999 to 2002 and B) Questionnaire showing record of incidents involving jellyfish used by the Santa Catarina Fire Service.

According to Haddad Jr. et al. (2002), one criterion for identifying the organism responsible for the incidents among bathers in the southeastern region of Brazil is the possibility of sighting the organism, together with the type of reaction observed. According to this criterion, the organisms responsible for the majority of cases recorded during the three summer periods were Hydromedusae, since the number of sightings was low and the effect observed mild. Thus it is also concluded that the identification made by the victims or by the lifeguard is for frombeing a foolproof process, and therefore requires inspection of the beaches by a trained team.

The species of cnidarians which present some risk of incidents, occurring on the Santa Catarina coast, include Physalia physalis (Siphonophorae), Chiropsalmus quadrumanus (Cubozoa) and Olindias sambaquiensis (Hydrozoa) (Migotto et al., 2002). P. physalis occurs sporadically on the beaches, but is more easily spotted and identified due to its pleustonic habit and the fact that it produces intense systemic effects (Haddad Jr. et al., 2002; Freitas et al., 1995 and Burnett, 2001). C. quadrumanus is common in coastal waters but does not get stranded on the beaches. This species is difficult for bathers to spot but the adverse reaction is similar to that of $P$. physalis (Haddad Jr. et al., 2002 and Mianzan \& Cornelius, 1999). On the other hand, $O$. sambaquiensis is very common on the beaches and is commonly known as "reloginho" (wristwatch), but is difficult to see in the water. It causes mild, local adverse effects such as edemas and erythemas (Haddad Jr. et al., 2002). There is also Scyphomedusa Lychnorhiza lucerna, which commonly gets stranded on the beaches, but presents low risk of stings, since it does do not have tentacles and its oral arms are adapted for suspensivorous feeding (Mianzan \& Cornelius, 1999), probably presenting nematocysts with little ability to pierce the human skin. Other dangerous jellyfish species occur also on Santa Catarina coast, including the cubozoa Tamoya haplonema (Morandini \& Marques, 1997) and scyphozoa Pelagia noctiluca (Mianzan \& Guerrero, 2000). However, they are rare and have not been recorded on local beaches.

It was observed that the treatment offered by the lifeguards demonstrated a lack of readiness and knowledge on their part for this type of incident, with vinegar being applied in only $13.1 \%$ of the cases. Various studies have highlighted the efficiency of the use of a mildly acidic solution as an emergency prophylactic treatment for this type of incident (Haddad Jr. 2000). However, this treatment only prevents the further discharge of the unfired nematocysts and is not recommended for all species 
(Mianzan et al., 2001). According to Burnett (2001), other types of treatment include: chilled seawater compresses and the use of a weak base such as soda in seawater, in cases where vinegar does not have the desired effect. However, it has not been possible to assess the efficiency of the various kinds of treatment used due to a the insufficient information provided by the victims after the incidents concerned.

On the northern coast of the State, crossreferencing incident data with prevailing winds indicated that $76 \%$ of the cases occurred with southerly winds (Fig. 2A), and at average speeds of above three $\mathrm{km} \cdot \mathrm{h}^{-1}$ (Fig. 2B).

These southerly winds favor the convergence of shelf waters on the beach regions, due to Ekman Transport, thus moving the organisms that are further out to sea towards the coastline (Mann \& Lazier, 1991). The correlation between incidents and prevailing winds had already been identified by Mianzan \& Zamponi (1988) on the coast of Argentina, with the occurrence of the hydromedusae Olindias sambaquiensis.

On the north coast, the highest number of incidents was recorded in the summer, when the average temperature was higher and the rainfall lower (Table 1). These results suggest that in summers with higher rainfall, the probability of incidents is reduced due to the lower frequency of bathers on the beaches. On the coast of Rio de Janeiro, the number of drowning incidents recorded by lifeguards is lower in summers when the water temperature is lower (David Szpilman, Fire Department of Rio de Janeiro, personal communication). However, the influence of the temperature and inflow of continental water in the coastal zone exerts over the distribution, reproductive activity and abundance of these organisms are only poorly understood.

\section{AcKNowledgments}

The authors are grateful to the Corpo de Bombeiros do Estado de Santa Catarina, for their collaboration and the data provided by them, which form the basis for this work, and to PETROBRAS (Petróleo Brasileiro S.A.), for its financial support for the Projeto Segurança nas Praias. Thanks are also due to Andrew Short, Lindino Benedett Filho, André Barreto and José Angel Alvarez Perez who helped in reviewing on an earlier manuscript.
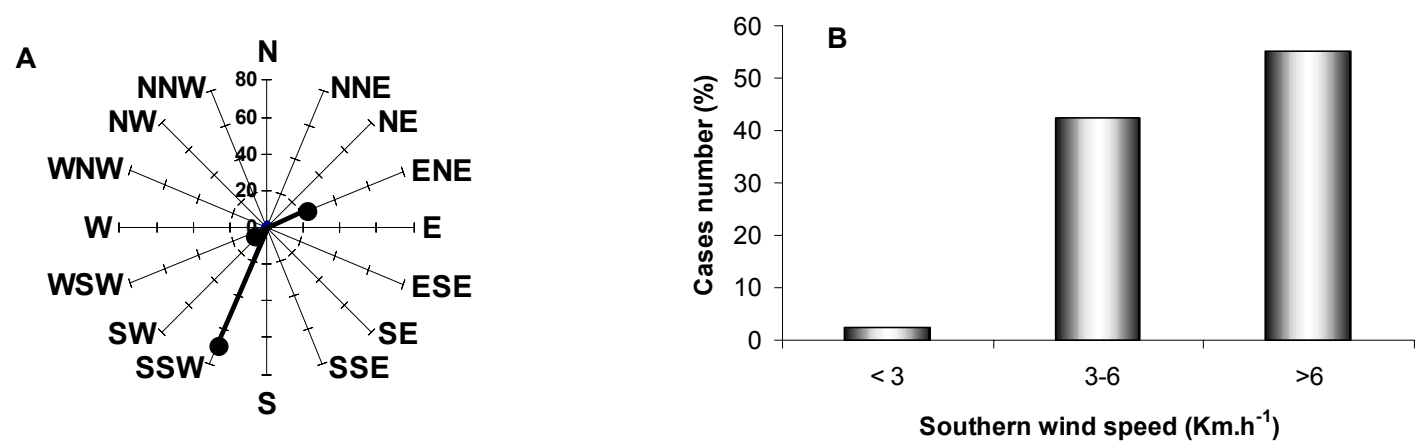

Fig. 2. Percentage of cases of jellyfish incidents for the northern coast of Santa Catarina the summers of from 1999 to 2002, inclusive according to: (A) wind direction and (B) frequency of classes of wind speed from the south quadrant.

Table 1. Average values for temperature, accumulated rainfall and number of incidents recorded for the northern coast of Santa Catarina during three summer periods (December to January) from 1999 to 2002, inclusive.

\begin{tabular}{ccccc}
\hline \hline Summer & $\begin{array}{c}\text { Temperature } \\
{ }^{\circ} \mathrm{C}\end{array}$ & $\begin{array}{c}\text { Rainfall } \\
\text { mm }\end{array}$ & Number & Cases \\
\hline $1999 / 2000$ & 24.70 & 216.2 & 13 & 12.4 \\
$2000 / 2001$ & 25.45 & 104.8 & 72 & 68.6 \\
$2001 / 2002$ & 24.95 & 134.0 & 20 & 19.0 \\
\hline
\end{tabular}




\section{REFERENCES}

Burnett, J. W.. 2001. Medical aspects of jellyfish envenomation: pathogenesis, case reporting and therapy. Hydrobiology, 451:1-9.

Freitas, C. J., Schiozer, W. A. \& Malpezzi, E. L. A. 1995. A case of envenoming by Portuguese man-of-War from the Brazilian coast. Toxicon., 33:859-861.

Fundação Nacional de Saúde. 1999. Manual de diagnóstico e tratamento por animais peçonhentos. VIII - Acidentes por celenterados. Brasília, Ministério da Saúde/FUNASA. p.97-99.

Haddad Jr., V. 2000. Atlas de animais aquáticos perigosos do Brasil: guia médico de identificação e tratamento. São Paulo, Editora Roca. p.145

Haddad Jr., V., Cardoso, J. L. C. \& Silveira, F. L. 2001 Seabather's eruption: report of five cases in southeast region of Brazil. Rev. Inst. Med. trop. S. Paulo, 43(3):171-172.

Haddad Jr., V., Silveira, F. L., Cardoso, J. L. C. \& Morandini, A. C. 2002. A report of 49 cases of cnidarian envenoming from southeastern Brazilian coastal waters. Toxicon, 40:1445-1450.

Hoefel, F. G. \& Klein, A. H. F. 1998. Environmental and social decision factors of beach safety in the central northern coast of Santa Catarina, Brazil. Notas Téc. FACIMAR, 2:155-166.

Mann, K. H. \& Lazier, J. R. N. 1991. Dynamics of Marine Ecosystems: Biological-Physical interactions in the Oceans. Oxford, Blackwell Science. 466p.

Mianzan, H. W. \& Cornelius, P. F. S. 1999. Cubomedusae and Scyphomedusae. In: Boltovskoy, D. ed. South Atlantic Zooplankton., Leiden, Backhuys Publishers. p. 513-559.
Mianzan, H. W.; Fenner, P. J.; Cornelius, P. F. S. \& Ramirez, F. C. 2001. Vinegar as a disarming agent to prevent further discharge of the nematocysts of the stinging hydromedusa Olindias sambaquiensis. Cutis, 68:45-49.

Mianzan, H. W. \& Guerrero, R. 2000. Environmental patterns and biomass distribution of gelatinous macrozooplankton. Three study cases in the Southwestern Atlantic. Scientia Marina, 64 (Supl. 1):215-224.

Mianzan, H. W. \& Zamponi, M. O. 1988. Estudio bioecológico de Olinidias sambaquiensis Muller, 1861 (Limnomedusae, Olindiidae) en el área de Monte Hermoso. II. Factores meteorológicos que influyen en su aparición. Iheringia, Ser. Misc. Porto Alegre, 2:63-68.

Migotto, A. E.; Marques, A. C.; Morandini, A. C. \& Silveira, F. L. 2002. Checklist of the cnidaria medusozoa of Brazil. Biota Neotropica, 2(1):31p.

Morandini, A. C. \& Marques, A. C. 1997. "Morbakka" syndrome: first report of envenomation by cubozoa (cnidaria) in Brazil. In: VII Congreso Latino-Americano sobre Ciencias do Mar, Resumos Expandidos, V.2, Santos. Inst. Oceanogr. USP. 188-189.

Nonato, E. F. 1992. Acidentes por celenterados. In: Schvartsman, S. ed. Plantas venenosas e animais peçonhentos. São Paulo, Ed. Sarvier. p. 248-250.

Santos Lima, E. A.; Volpato, L. K.; Grando, M.; Benato, V. S.; França, F. O. S. \& Zannin, M. 1996. Acidentes provocados por Physalia sp (Caravelas): 238 casos relatados no litoral catarinense. Rev. Cien. Saúde, Florianópolis, 15(1/2):275-282.

(Manuscript received 15 February 2005; revised 04 November 2005; accepted 22 November 2005) 